\title{
Aspleniaceae of Tandikek Mountain, West Sumatra
}

\author{
Mildawati $^{*}$, Ardinis Arbain ${ }^{1}$, Hary Fitrah ${ }^{1}$ \\ ${ }^{1}$ Biology Department, Faculty of Mathematics and Natural Sciences, Andalas University
}

\begin{abstract}
Research on ferns of Aspleniaceae family of Tandikek Mountain in West Sumatra, Indonesia has been done through a survey method and direct collection in the field, followed by a study at Herbarium of ANDA (Andalas University). Eleven species consisting of Asplenium affine, A. batuense, A. belangeri, A. pellucidum, A. phylitidis, A. robustum, A. salignum, A. scalare, A. tenerum, A. unilateralis, and Asplenium sp1. have been found as part of the Asplenium genus. The species of Asplenium genus have been obtained from the elevation of $1231-2336$ meter above the sea level.
\end{abstract}

Keywords: Aspleniaceae, Tandikek Mountain, West Sumatera

\section{INTRODUCTION}

Tandikek Mountain is located in Tanah Datar, West Sumatra, Indonesia. The topography of Tandikek Mountain has a maximum elevation of 2.437 meters above sea level. One of the floras found in Mount Tandikek is fern. Fern is cormophyta with spores that can live anywhere (cosmopolitan). Abundance and distribution of fern is very high, especially in the area of tropical rainforest and many are in the mountain forests [1]. According to [2], ferns are high diversity species and are widely spread. [3] States that the number of ferns in the world is approximately 10,000 species spread throughout the tropics and subtropics.

One of the members of fern is Aspleniaceae. Aspleniaceae is one of the richest species among leptosporangiate ferns, with 720 teresterial, epilithic or ephyphytic ferns [4]. [5]Places ferns with linear sori and vascular bundle is a genus of Asplenium. [6, 7] find that the sporangia of Aspleniaceae are long stalked as a typical of Leptosporangiate ferns. The existing familes of Aspleniaceae with " $\mathrm{X}$ " shape vascular bundles onthe upper petiole was found firstly by [8].

\footnotetext{
${ }^{*}$ Corresponding author:

Mildawati

Biology Department, Faculty ofMathematics and Natural

Sciences, Andalas University

E-mail: mildawati_2011@yahoo.co.id
}

[9] has been the -first who based aspleniaceae classification on phylogenetics assumption by taking into account the relationship between species groupings. [10] publishes the characteristic of Asplenium group, that is a sory distinctly elongate along the veins, segments of frond usualy with more than one vein, and sori all facing the same way except in a few species which have simple fronds and then the raised line between adjacent sori is lacking.

Indonesia is one of the areashaving rich biodiversity in the world. Researchon the inventarization of ferns Indonesia isdone by [11]in National Park Laiwangi-Wanggameti NTT; the studyhas found about 21 family, 30 genus, and 70 species of ferns. There are 8 species of Aspleniaceae among them. Indonesian Institute of Science (LIPI)[12] publishesa report about ferns in Indonesia, andamong the 54 described species, three of them are Asplenium. They are Asplenium belangeri (Bory), Asplenium nidus L. and Asplenium tenerum Forst. [13]Reports25 species of the seven families in Tourism Area of Minangkabau Village in Padang Panjang. [14] Reports 11 species of four families in Bung Hatta Forest Park Padang.

Research about species of the Aspleniaceae ferns family from Tandikek Mountain West Sumatra has never been done. There has never been a report of herbarium speciment at Herbarium of Andalas University. Under these conditions, it is important to conduct research to 
examine the Aspleniaceae species of Mount Tandikek West Sumatra Indonesia.

\section{MATERIALS AND METHODS}

The study on the morphological diversity of the Aspleniaceae Family took place at Mountain Tandikek in Tanah Datar, West Sumatra, Indonesia and was continued at the Laboratory of Plant Taxonomy and Herbarium of the Biology Department, Andalas University (ANDA) in Padang. The materials used in this study were methylene blue, $70 \%$ alcohol, and distilled water. The tools used were shears, oven, newsprint, plastic bags, bottles collection, field labels, tweezers, glue, white paper board, clips, binocular microscopes, light microscopes, cameras, and stationery. The method used in this study was survey and sample collection in the field. At the location of the research, data was collected by way of collecting and recording field data such as the habit of the plant, frond, stem color, leaf color, shape and location of the sorus [15]. Further herbarium specimen was made. The process of making specimens was held based on [16]. A herbarium is a collection of dried plants systematically named and arranged for references and study. To make a herbarium specimen, the plant is collected, and notes are made about it. The plant is then pressed until dry between blotters that absorb moisture and mounted into a herbarium sheet with a suitable label. Identification of specimens is done using literature in accordance with the following reference: $[1,8,17,18,19]$.

\section{RESULTS AND DISCUSSION}

Tandikat is a mountain located in the Highlands of Minangkabau, of approximately 7.5 $\mathrm{km}$ from the city of Padang Panjang, West Sumatra, Indonesia. The mountain is stretched wide to the south, and to the west bordering the lake. On the northern side of the mountain there is Mount Singgalang, while on the east side there is an old cluster of tertiary volcanic mountains. The mount type is strato volcano, which is also known by the name of Tandikek in Minangkabau language. It is very relevant to point out here that twoMountains have always been rich in biodiver- sity. One of them is ferns (Pterydophytes). Ferns have high adaptability, which can be found living everywhere, such as in humid areas, under trees, on riverbanks, steep slopes, in the mountains and even many that are attached to tree trunks, grow on rocks or soil Wiesner, 1907 and Went, 1940 in [20].

Inventory study on ferns in mountain forests of Betung Wan Abdurahman botanical garden in Bandar Lampung was done and 30 species and 14 families found [21]. Aspleniaceae is the most dominant species of ferns. Index diversity of ferns at Mount Betung is moderate $\left(\mathrm{H}^{\prime}=2.9817\right)$. Ferns are widely distributed, but they have a number of species that are still not established. It is estimated about 12,000 types of ferns that include 400 genera and 36 families in the world $[22,12]$. About 1,300 of them are found in the Malesiana [23]. It is estimated that there are 700 - 750 species of Aspleniaceae in the world [4].

\section{Species of Aspleniaceae that found in Tandikek Mountain West Sumatra}

Observation and exploration of ferns conducted at Mount Tandikek, West Sumatra in Indonesia was done and as many as 189 sheets spesiment were collected. There were 63 samples taken. Eleven species from the 63 samples obtained were classified into the family of Aspleniaceae. [24] explains that the genera of Asplenium and Athyrium are the genera found in the forests of North America such as Alaska and Canada. [25] find that of the 31 genera, 16 genera, and 6 family ferns used in the study are classified as much as $39 \%$ and $22 \%$ family of Polypodiaceae and genus Asplenium.

The species of Asplenium genus on Aspleniaceae family found in Tandikek Mountain can be seen at Table 1 below. Based on Table 1.1, it can be seen that the ferns of Aspleniaceae family taken from Tandikek Mountain West Sumatra, Indonesia consists of 11 different species. Among the species discovered, there are Asplenium affine Sw., A. batuense, A. belangeri, A. pellucidum, A. phylitidis, A. Robustum, A. Salignum, A. scalareaeRosenst, A. tenerum, A. unilateralis, and Asplenium sp1. [26] States that Aspleniaceae is one of the biggest families of ferns and ferns allies. This family is estimated to have 700 - 750 species and has a worldwide distribution.Tandikek mountain ferns 
Tabel 1. Species of ferns Family of Aspleniaceae from the samples taken at Mount Tandikek West Sumatra

\begin{tabular}{|c|c|c|c|}
\hline No & Species & Coordinate & $\begin{array}{c}\text { Elevation } \\
\text { (M. above sea level) }\end{array}$ \\
\hline \multirow{3}{*}{1.} & & S.0650609 & \\
\hline & Asplenium affine $\mathrm{Sw}$. & E.9952742 & 1243 \\
\hline & & S.0650402 & 1320 \\
\hline \multirow[t]{2}{*}{2.} & Asplenium batuense V.A.V.R & E.9952790 & \\
\hline & & S.0650642 & 1231 \\
\hline \multirow[t]{2}{*}{3.} & Asplenium belangeri (Bory) Kze. & E.9952758 & \\
\hline & & S.0650498 & 1286 \\
\hline \multirow[t]{3}{*}{4.} & Asplenium pellucidum Lam. & E.9952763 & \\
\hline & & S.0650590 & 1241 \\
\hline & Asplenium phylitidis Don Subsp. & E.9952730 & \\
\hline \multirow[t]{2}{*}{5.} & Malesicum Holtt & & \\
\hline & & S.0650534 & 1260 \\
\hline \multirow[t]{2}{*}{6.} & Asplenium robustum $\mathrm{Bl}$. & E.9952759 & \\
\hline & & S.0646889 & 2336 \\
\hline \multirow[t]{2}{*}{7.} & Asplenium salignum $\mathrm{Bl}$. & E.9952369 & \\
\hline & & S.0649984 & 1362 \\
\hline \multirow[t]{2}{*}{8.} & Asplenium scalareaeRosenst & E.9952979 & \\
\hline & & E.0647875 & 2018 \\
\hline \multirow[t]{2}{*}{9.} & Asplenium tenerum Forst & S.9952426 & \\
\hline & & S.0659454 & 1496 \\
\hline \multirow[t]{2}{*}{10.} & Asplenium unilaterale Lam. & E.9952746 & \\
\hline & & E.0646861 & 2361 \\
\hline 11. & Asplenium sp1. & S.9952419 & \\
\hline
\end{tabular}

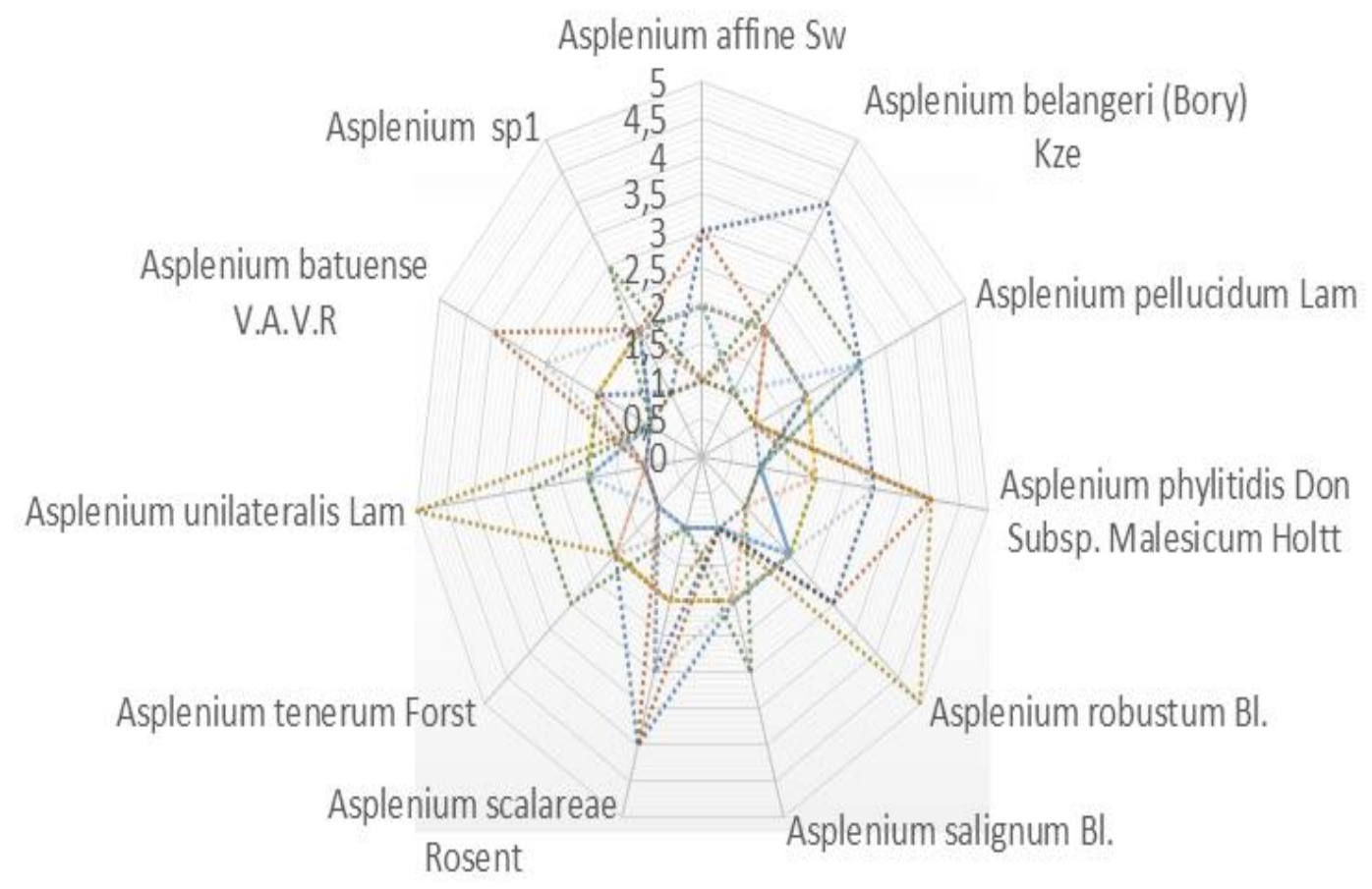

Figure 1. Distribution of ferns family Aspleniaceae by rhizome morphological characters, frond, lamina and sorus 
are found from the elevation of 1,100 m - 2,400 $\mathrm{m}$ with a very diverse number of species.Based on measurement, the Asplenaceae in Tandikek mountain of West Sumatra were found from the altitude of $1231 \mathrm{~m}$ to $2361 \mathrm{~m}$. The altitude of $1200 \mathrm{~m}$ has the most abundant family of Aspleniaceae. The most optimal life for ferns is at the altitudes above 600 meters [3]. Based on the data obtained, the distribution of most species of ferns is found at altitude of 1000-1500 $\mathrm{m}$. For the altitude above $1,500 \mathrm{~m}$, the species obtained are very limited.

Ferns is transitional vegetation between thalophyta to chormophyta, because ferns have a mix of nature and form of the moss to higher plants [27]. Ferns have been identified to have around 11,000 species throughout the world; this number is classified into 400 genera and 36 families. [28] States that genus having the largest number of species are Asplenium and Cyathea, each consists of approximately 700 species. [28] States that the tropic is the center to ferns biodiversity, in which the total number of species exceeds $50 \%$ of the total species identified.

\section{ACKNOWLEDGMENT}

We would like to send our gratitude to University of Andalas, DIPA Year 2012 for funding this research. We would also express my gratitude to the Dean of the Faculty of Mathematics and Natural Sciences, Andalas University Padang, the Chairperson of the Biology Department, Andalas University Padang, and the students of the Biology Department, Andalas University Padang, and all the parties having provided assistance.

\section{REFERENCES}

1. Ewusie JY (1990) Pengantar Ekologi Tropika. ITB. Bandung.

2. Tjitrosoepomo G (1992) Taksonomi Tumbuban Rendah (Taksonomi Tumbuhan Khusus). Gadjah Mada University Press. Yogyakarta.

3. Holttum RE (1967) A Revised Flora of Malaya Volume II. Ferns of Malaya. Government.

4. Kramer KV and Viane RLL (1990) Aspleniaceae In : The family and Genera of Vascular plants. Vol. I. Pterydophyteae and Gymnospermae. Berlin. Springer Verlag. $52-57$.
5. Linnaeus C (1753) Species Plantarum, exhibentes plantas rite cognits ad genera relatas, cum differentiis specificis, nominibus trivialibus, synonymis selectis, locis natalibus, secundum systema sexuale digestas, Tomus II.L. Salvius. Stockholm.

6. Bower FO (1926) The Ferns Vol II. London. Cambridge University Press.

7. Bower FO (1928) The Ferns Vol III. London. Cambridge University Press.

8. Copeland EB (1947) Genera Filicum. Chronica Botanica, Waltham, Mass.

9. Holttum RE (1967) A Revised Flora of Malaya Volume II. Ferns of Malaya. Government Printing Office. Singapore.

10. Holttum RE (1959) Series II - Pterydophyta Ferns and Ferns Allies. Flora Malesiana. Vol I.

11. Darma IDP and Peneng IN (2007) Fern Inventorization in Laiwangi-Wanggameti National Park, East Sumba, Waingapu, NTT. Biodiversitas. 8: $242-248$.

12. LIPI (1980) Jenis Paku Indonesia. Lembaga Biologi Nasional. LIPI. Bogor.

13. Lamid DM (2007) Jenis-JenisPaku Epifit yang Terdapat di Kawasan Wisata Perkampungan Minangkabau Padang Panjang. Skripsi Sarjana Biologi FMIPA Universitas Andalas.

14. Mildawati (2011) Tumbuhan paku epifit di Taman Hutan Raya Bung Hatta Kota Padang. Proceeding Seminar Nasional MIPA dan Pendidikan MIPA. FMIPA UNP. Padang. 19-20 November 2011.

15. Pryer K.M, Scuettpelz E, Wolf PG, Schneider H, Smith AR, Cranfill R (2004) Phylogeni and volution of Ferns (Monilophytes) With A Focus on The Early Leptosporangiate Divergences. American Journal of Botany. 91(10): 1582-1598.

16. Jain SK and Rao RH (1977) Hand Book of Fieldand Herbarium Methods. Today and Tomorrows Printers and Publishers. New Delhi.

17. Andrew SB (1990) Ferns of Queensland. Queensland Department of Primary Industries.

18. Johnson A (1960) Student Guide to the Ferns of Singapore Island. Singapore University Press. Singapore.

19. Piggott AG (1988) Ferns of Malaysia in Colour. Tropical Press SDN. BHD. Malaysia.

20. Hasar A and Kaban B (1997) Prinsip-prinsip Dasar Ekologi. PT. Raja Grafindo Persada. Jakarta.

21. Ellyzarti and Gusniati (2011) Potensi Kekayaan dan Keanekaragaman Jenis. Paku-Pakuan (Pteridophyta) Di Gunung Betung Taman Hutan Raya Wan Abdurahman Bandar Lampung. Jurusan Biologi Fmipa Universitas Lampung. http://Fmipa. Ipb.Ac.Id/Index.Php/Id/Biosains. 
22. Sastrapradja SJJ, Afriastini, Darnaedi \& Elizabeth (1980) JenisPaku Indonesia. Lembaga Biologi Nasional. Bogor.

23. Schmitt JL and Windisch PG (2010) Biodiversity and spatial distribution of epiphytic ferns on Alsopilasetosa Kaulf. (Cyatheaceae) caudices in Rio Grande do Sul, Brazil. BrazJ Biol. 70(3): 521 528.

24. Johnes SBJr and Luchsinger AE (1979) Plant Sistematics. Second edition. Mc Grawhil International Edition.

25. Tryon R (1992) Pteridophytes. In: H. Lieth and M. J. A Werger (Editor), Tropical Rain Forest Ecosystem. Elsevier Science Publisher B. V. Netherland.

26. Rambe (2008) Aspleniaceae in phylogeny and Biosystematic. Biosainstifika. 1: $88-100$.

27. Raven PH, Evert RF, Eichorn SE (1992) Biology of Plants. Worth Publishers. New York.

28. Haufler CH (2006) Fern and Fern Allies. http:/ / ftp.rbgkew.org.uk/scihort/ferns.html. Accessed date: February 19, 2010. 